\title{
情報環境とサービスの統合デザインで価值を創る デジタルセンセーション株式会社
}

\section{1.まえがき}

デジタルセンセーション株式会社は, 2004年 10 月にテレビジョン発祥の 地である静岡大学浜松キャンパスで, 知的クラスター創成事業「浜松オプト ロニクスクラスター」の支援を受け， 情報学部の教員が設立したITベンチャ 一です1).「文工融合」の理念のもと， 「情報技術と映像コンテンツ」を両輪と し，人間社会の二ーズに焦点をあてた ウェブ映像コンテンツと, ネットワー クサービスに関わる基礎研究と応用開 発を進めています．創業から現場主義 で6期連続黒字経営を続けてきました が, 今後の飛躍に向けて社長の坂根裕 は2009年3月に静岡大学を退職し， ネットワークシステム, 医療機器検査 システム, ウェブ映像コンテンツ制作, インターネット映像配信関連で, 若い 社員を率いて価值創造型ビジネスに挑 戦しています。

本稿では, 当社の事業概要とこれま での取組みについて述べ，現場主義の 独創的なライブ映像配信技術とサービ 又技術を紹介し, 最後に今後の事業展 開について述べます。

\section{2. デジタルセンセーション}

社名の「デジタルセンセーション

\footnotetext{
†デジタルセンセーション株式会社

$\dagger †$ 静岡大学創造科学技術大学院

"Value Creation by Superior Technologies for Designing Information Environments and Services" by Yutaka Sakane (Digital Sensation., Co, Ltd., Shizuoka) and Yoichi Takebayashi (Shizuoka University, Shizuoka/Digital Sensation. Co., Ltd., Shizuoka)
}

(Digital Sensation)」は, 当社の事業 コンセプトを示すものです，会長の竹林 洋一は, 1998年に東芝とMITの研究于 ームが中心となって開催した, ウェアラ ブルコンピュータのファッションショウ の内容について3日間集中的に議論し， ユビキタス情報社会の将来像を描く機会 を得ました. その結果,「箱屋(機器)」, 「土管屋(ネットワーク)」,「石屋 (セミ コン)」などの個別の技術や発想だけでは 産業のパイを拡大できないことを確信し ました。

人間・社会・環境に膨大な数のデバ イスやセンサが埋め込まれる超情報化 社会においては, 人間社会の複雑な問 題や多様な要求に応えることが重要視 され，「技術とコンテンツ」の有機的連 携が不可欠であると考えました，その 時に生まれたコンセプトが「デジタル センセーション」です2)3)、「膨大なセ ンサ情報から人間の意図や状況を理解 し, 状況に応じて適切なコンテンツを 提供する」というユビキタス情報社会 における研究開発の発展シナリオであ り，ITビジネスの成長戦略であるとも 言えます

\section{3. インターネットライブ配 信サービスの取組と問題 意識}

当社は, 2006年 11 月に開催され た第6回浜松国際ピアノコンクールで, 初めて多数のネット視聴者向けに映像 配信をしました. 第1次予選から本選, 入賞者披露演奏会までの13日間すべ てにわたって，ライブ配信と (演奏後 15分以内に公開する) オンデマンド配
信を同時に行いました，幾度もウェブ サーバや配信サーバが落ちかけ（実際 ウェブサーバは何度か再起動し)まし たが，どうにか最後まで持ちこたえま した. 当時, ピアノコンクールをライ ブ配信するという試みは幾つかありま したが，最後までやり通せたサービス は少なかったようです

ネットやサーバ性能が向上するにつ れ，ライブ配信サービスの可能性は広 がります。しかし, この頃から, ベン チャーや中小企業では,「ライブ配信 サービスはビジネスが難しい」という 問題意識が芽生えてきました。理由は いくつかあります.

ライブ配信サービスには必要な要素 技術が多く，それぞれを異なる会社や 団体が担うことが多いため, システム 全体が複雑になりがちです，大雑把に 列挙しても，撮影・録音，エンコーダ 運用, 配信サーバ運用, 配信ページ (プレーヤ)制作・運用などがあります． このことは，イベント企画・運営者で ある顧客にとって，「なんだか解らな いモノ」「トラブルが起きないか心配」 など，不安感を与える要因となります． また，技術要素毎に担当が異なること は，システム全体を俯瞰して設計・管 理できる技術者がいないということで す、トラブル時の対応や，新しいアイ デアをサービスに組込むことは容易で はありません．

この問題に対して当社では，(1)サー ビスのモデル化手法, (2) ネットユーザ 群の制御技術，(3) ユーザとの対話技術 を開発することで，解りやすく拡張性 に優れたライブ配信サービスのソリュ 


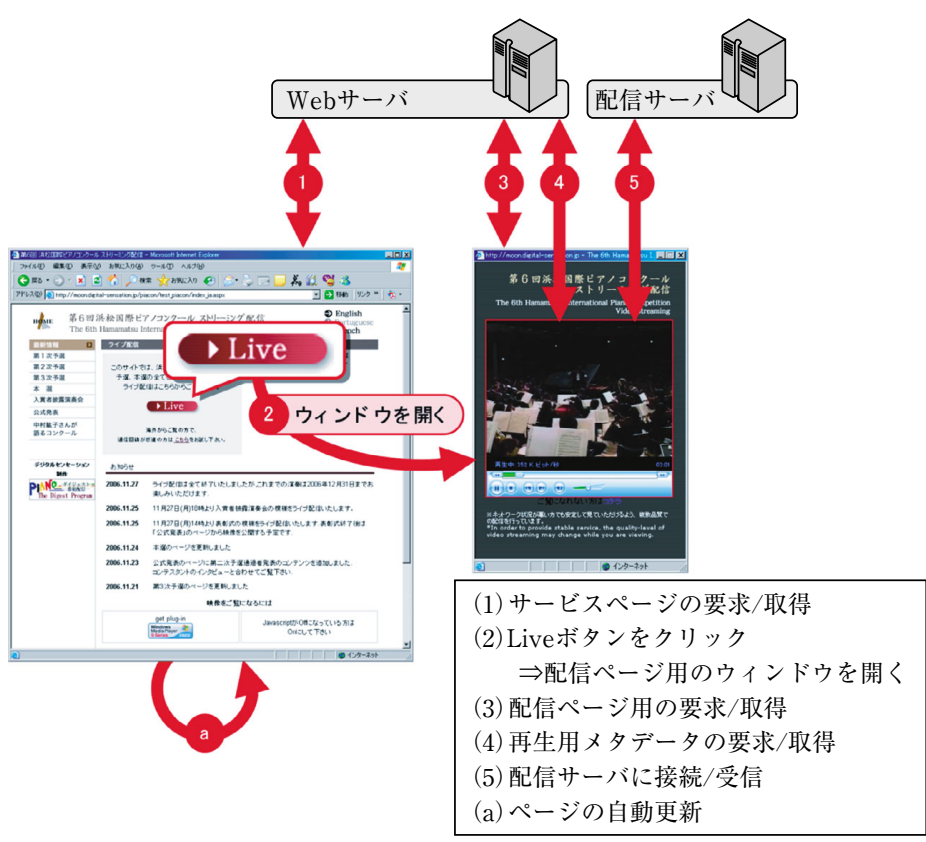

図1 ライブ配信サービスを2状態で管理

\section{ーションを提案しています。}

\section{4. ライブ配信サービスを支 援するソフトウェア技術} 2006年のピアノコンクールでは ,
ライブ配信サービスの状態を、「配信 時間外」と「配信中」の2状態で管理し ていました(図1)。配信時間外では, 配信ページへのリンク (Liveボタン)を 非表示にしておき，時間になるとリン
クを表示し, 番組終了時には映像が途 切れることで，本当に終了したと視聴 者に理解させました，このとき，「と にかく映像を流す」という目的は達成 できましたが，当時のサービス内容に は不満が残りました。

\section{1 サービスのモデル化手法}

より詳細なライブ配信サービスの状態 を「表現」するために，サービス運営を 「劇場の運営」と比較してみます(図2). 図2の劇場には，場內と場外がありま す，場内には，舞台，座席，場内用ス ピーカがあります，場外にも場外用の スピーカがあります，チケットは事前 販売せず，当日販売のみとします。こ れらの概念でライブ配信サービスを説 明してみます。

劇場に訪れた客(配信ページにアク セスしたユーザ)は, まだ会場の扉が 開いてなかったため(配信準備が整つ ていないため), 場外に到着順に並ん で待ちます(アクセス順に待機します). 場外で待っている亡,「あと10分です」 というアナウンスが流れてきます(「あ と10分です」というメッセージが画面

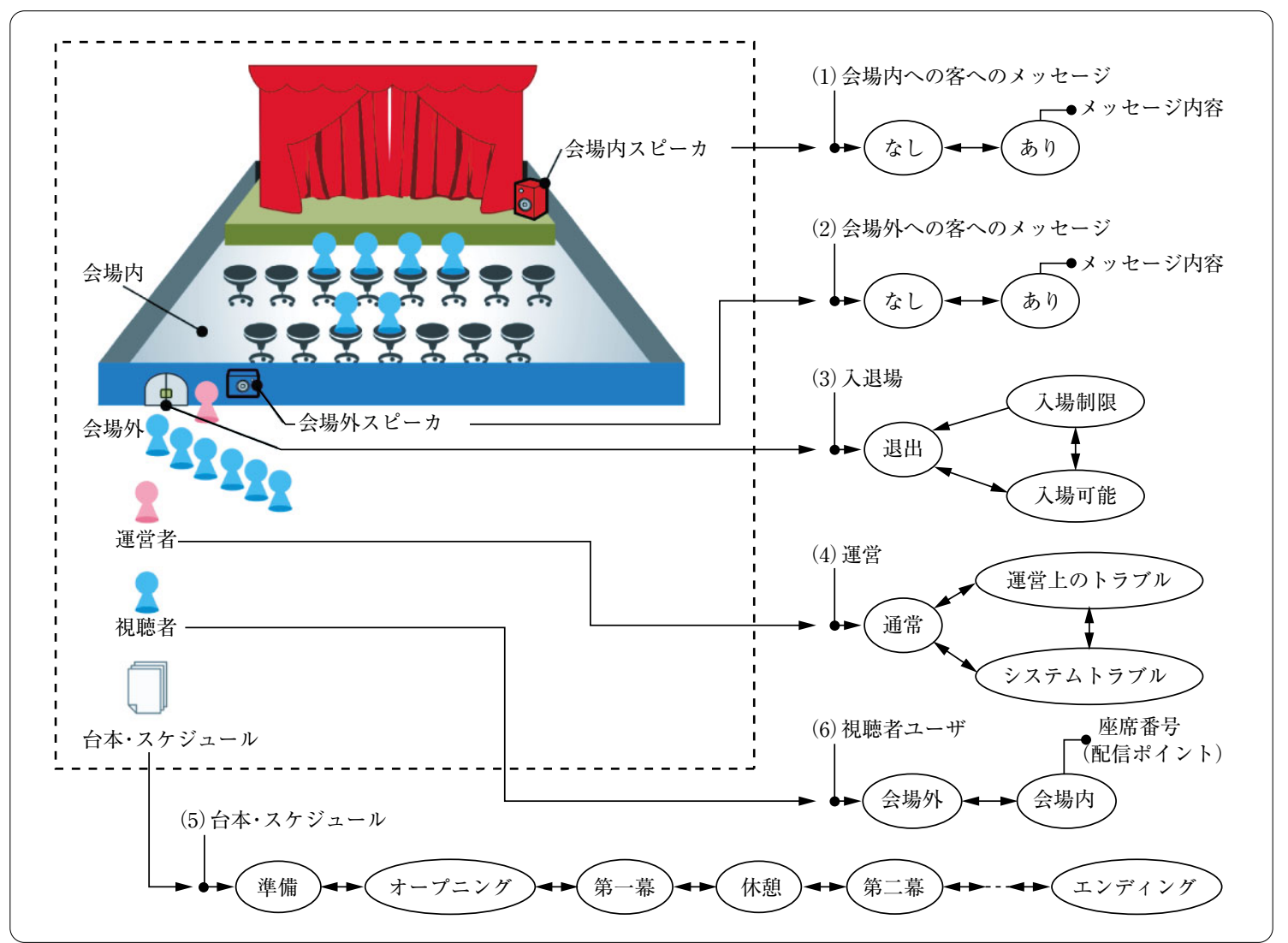

図2 劇場概念でのライブ配信サービスモデル 

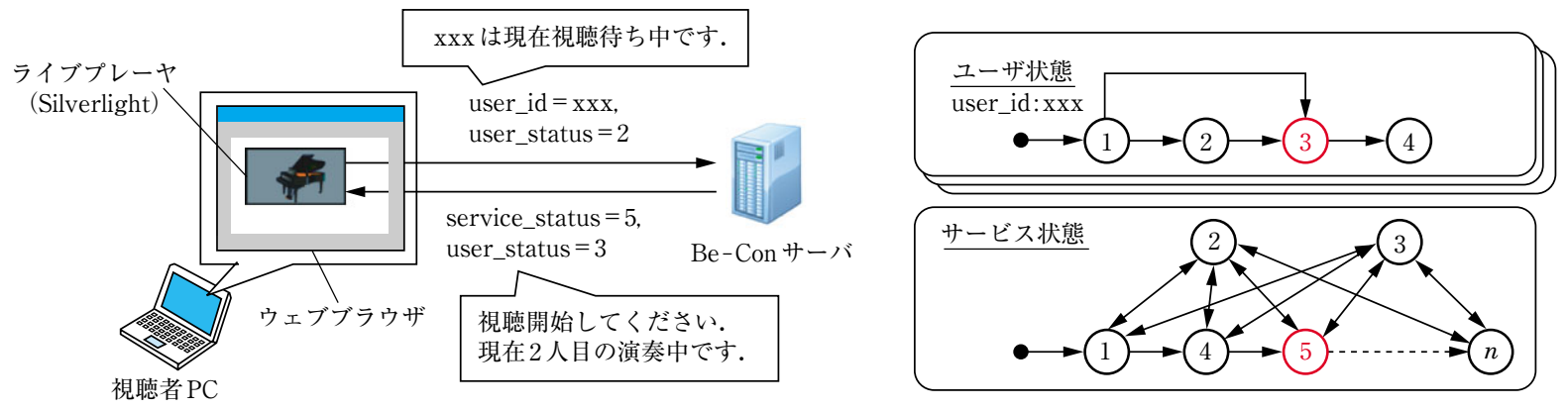

図3 Be-Con (Behavior Controller) の処理概要

\section{上に表示されます）.}

扉が開くと同時に会場内に入り，チ ケットに書かれた席に座ります（待機 順に，指定された配信サーバに接続し ます)，劇は始まってないため幕が閉 まっています (準備中の映像が流れて います），時間になると幕が開き，才 ープニングが始まります（本編映像が 流れ始め，画面に「オープニング」であ ることが表示されます).オープニン グ後は第一幕が始まります（映像はそ のまま流れ，画面に「第一幕」であるこ とが表示されます).

休㦝時間になると幕が閉じ（映像が 消え「休㮩中」の文字が表示され）， 「20分休憩」であることが場内にアナ ウンスされます（「休鄎時間は20分」の メッセージが表示されます). 20分後, 再び幕が開き，第二幕が始まります （映像が再び流れ始め，「第二幕」であ ることが表示されます).

第二幕の途中で地震が発生します (システムトラブルが発生します)。幕 は一旦閉じられ (映像が一旦停止し)， 「慌てず，そのまましばらくお待ちく ださい」と場內アナウンスが流れます (「システムトラブルが発生しました. 復旧するまでしばらくお待ちくださ い」と画面に表示されます). その後, 「再開します」というアナウンスととも に幕が開きます(メッセージが消え， 映像が流れ始めます).

場内の座席がすべて埋まった後に， 別の客が到着します (視聴可能数を超 えて，新たなユーザが配信ページにア クセスします)。中には入れませんの
で，扉の前で並んで待ちます(視聴開 始せずに待機します)，場内から客が 一人出てきて帰ってしまいます(視聴 中のユーザがブラウザを閉じてしまい ます). 帰ってしまった客の代わりに, 待っていた客が場内に入ります（優先 度が最も高い待機中のユーザが配信サ 一バに接続します)

劇が終わり，幕が閉じます（映像が 消えて，「本日の配信はこれで終了で す」メッセージが表示されます)，客は 席から立ち上がり劇場を後にします (ユーザはブラウザを閉じます).

このように劇場のメタファー (概念) で考えると, ライブ配信サービスは， 図2に示す (1) から (5) までのサービ ス状態と，（6）のユーザ状態に分けて 考えることができます，サービス状態 は全ユーザで共通したデータであり， ユーザ状態はユーザ毎に異なります． つまり，サービスの状態を，（( 1 ）, (2), (3), (4), (5)) =(なし, なし, 入場可能, 通常, 準備中) や ("暫くそ のままお待ちください”，なし，入場 制限，運用上のトラブル，第二幕）上 表現できるようになります，このよう にサービス全体をモデル化すると，こ れまで表現が難しかった「ライブ配信 サービスの状態」を, 単純な数個の值 の組合せで表現できるようになりま 于.

\section{2 ネットユーザ群の制御技術}

有限の配信サーバとネットワーク帯 域を上手に利用するためには，各ユ一 ザに勝手に配信サーバへ接続させては いけません，劇場を仕切る運営者のよ
うに, 状況に応じて視聴者を適宜並ば せたり，順番に場內へ案内したりする 仕組みが必要です，当社では，各ユ一 ザから情報を収集し，全ユーザの歩調 を同期させながらサービス運営する技 術として, Be-Con (Behavior Controller)を開発しました.2009 年 11 月の第7回浜松国際ピアノコンク 一儿配信で実運用し，安定した配信を 実現しました。

図3にBe-Conの処理概要を示しま す．各ユーザ(の映像プレーヤ)は, 一 定時間毎に自身の状態をBe-Conサー バに通知します。Be-Conサーバは, 通知を受け取るとサービス状態とユー ザ状態を返却します。映像プレ一ヤは 返却された状態を見て，「メッセージ を表示する」「映像を停止する」など， 自身のユーザインタフェースを適切に 変更します。Be-Conサーバは，一定 時間ユーザから状態通知がないと, 「ユーザは劇場を後にした(帰った)」と 判断し, 待機状態のユーザを視聴状態 へ誘導 (接続先配信サーバを通知) しま す．図4は，ピアノコンクール配信時 に開発したプレーヤです.Be-Conサ 一バからの情報を基に，ユーザインタ フェースが適切に切替わります.

現在, ピアノコンクール配信で開発 したシステムを改良し，現場の人間が 少人数でサービス運用できる実践的な システムを, 関係会社と協力しながら 開発しています (図5) ${ }^{4) 5) 。 サ ー ヒ ゙ ス ~}$ の状況把握と制御は, スマートフォン などの携帯端末から行えます．本シス テムを, 既存のライブ配信技術と組合 
せて利用することで，解りやすく使い やすいサービスが実現できます

\section{3 ユーザとの対話技術}

当社では, ネット配信サービスのビ ジネスの成長は, 高画質・高音質化よ りも，映像を「ツマミ」としたネット上 で楽しめる，ドメインに特化したサー ビスの提供にあると考えています，最 近, ネットユーザと議論しながら視聴 できる，映像+Twitter等の組合せがい ろいろと出てきましたが，ライブ映 像十 $\alpha$ の,「対話機能デザイン」も重要 になると考えています，例えば，スポ 一ツの試合を「監督」視点として見る （自分が監督なら出す「指示」を，他ユ 一ザと共有し盛り上がる)」，「格闘技の 試合を選手視点で見る(自分ならここで 「こう攻める!」を共有し自慢する)」な ど，ドメイン特化した「遊び」を提供す るのです

これまで開発してきた対話技術の一 例を紹介します，図6(左)は，ライブ 映像を見ながら，CM映像も見せると いうものです．バナーをクリックする 亡, ライブ映像が右下隅に移動し， CM映像が再生されます，ライブ映像 は半透明になり，音のレベルも抑えま す，マウスカーソルをライブ映像に合 わせると，ライブ映像が少し大きくな ります．クリックするとCM再生は停 止しライブ映像に戻ります

図6(右)は,コンテンツ自体に対話 機能を組込んだ, BalloonNavi ${ }^{\mathrm{TM}}{ }^{\mathrm{N}}$ です． 単に映像再生するだけではなく, 適宜 視聴者に質問し，その回答に応じて内 容を变更します，ユーザはコンテンツ からの質問に対し，「吹き出し」をクリ ックする(またはクリックしない)こと で回答します，アンケートや接客, 教 育用途などに広く応用できます。

また，これらの技術をライブ配信サ ービスに組込むノウ八ウとして，「時 刻のずれ」を吸収する工夫が重要です． インターネットのライブ配信では,さ まざまな意味で時刻がずれます，まず， 現場の時刻 (現場時刻) とネットユーザ が見ている映像内の時刻 (映像内時刻) は，技術的な問題で数秒から数分ずれ

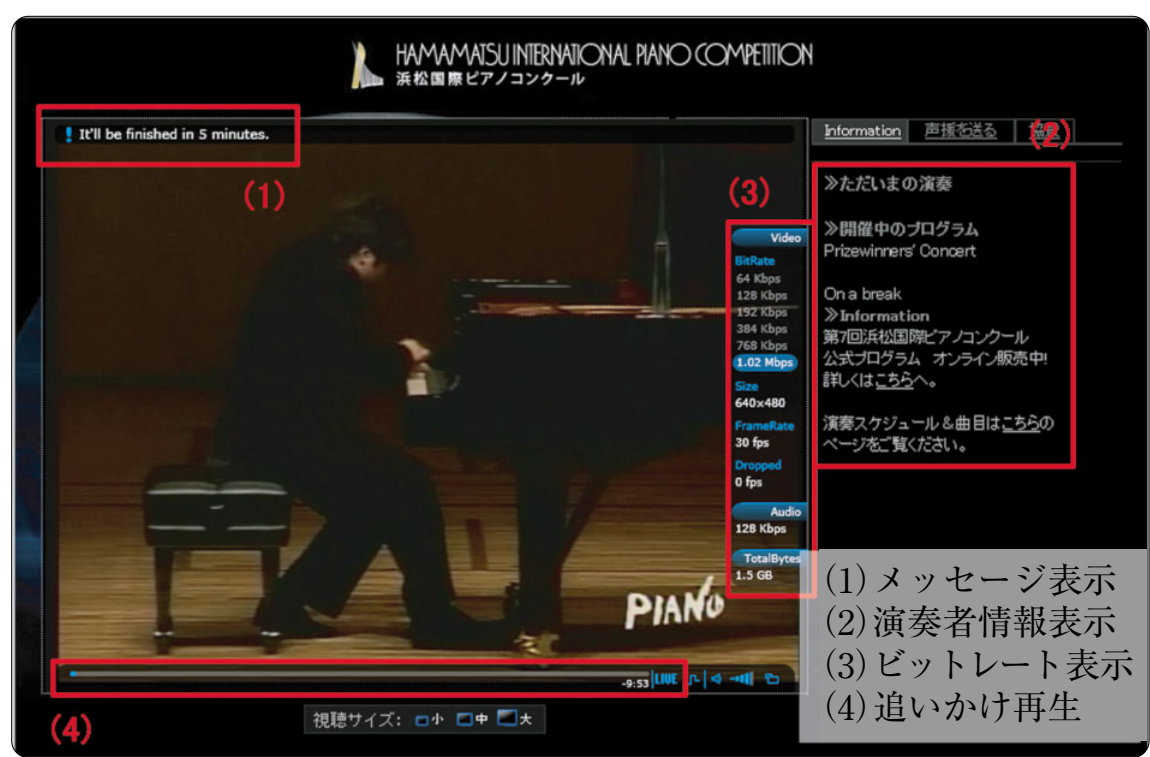

図4 新モデルでのライブ配信サービス

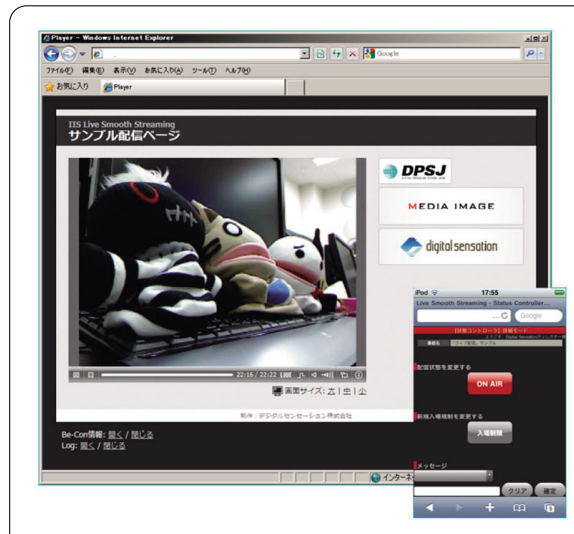

配信状態

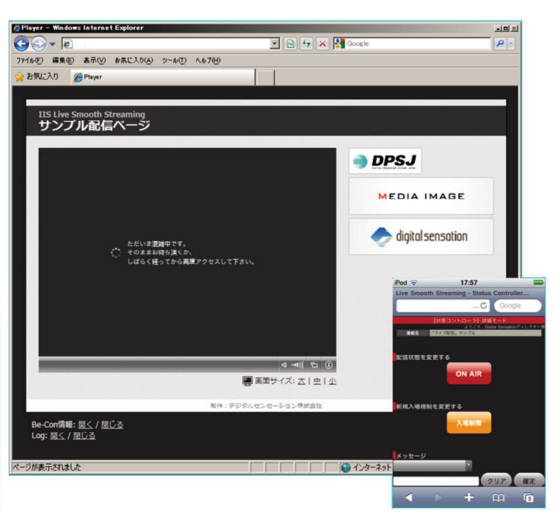

入場制限状態

図5開発中のライブ配信サービス支援ツール
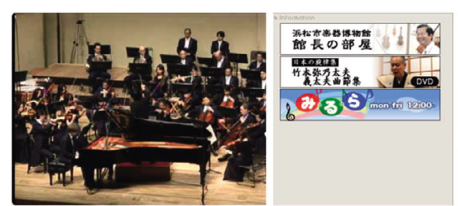

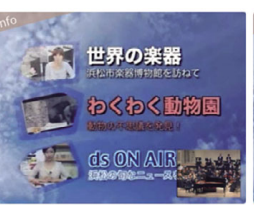

(a) ながらCM

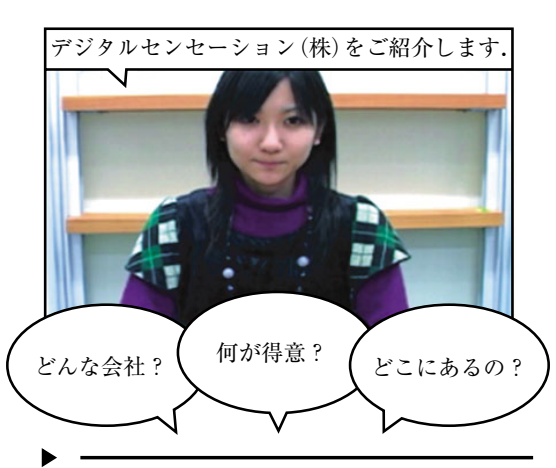

(b) BalloonNavi ${ }^{\mathrm{TM}}$

図6 対話技術の一例

ます。ささらに、ネットユーザ毎に映像 内時刻のずれは大きさが異なります． 同じネットワークに接続している2台 のコンピュータでも時刻がずれている
ことがあります．一見大した問題に見 えませんが，意外に深刻です，例えば， サッカーの試合を直接見ているユーザ が,「ゴール!」と入力したときに，ま 


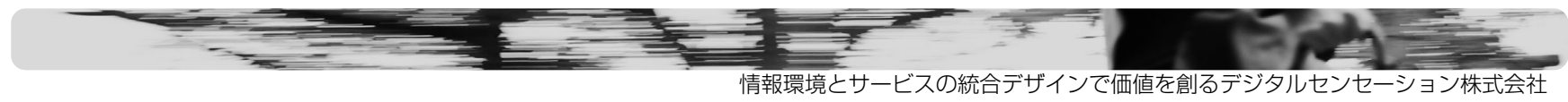

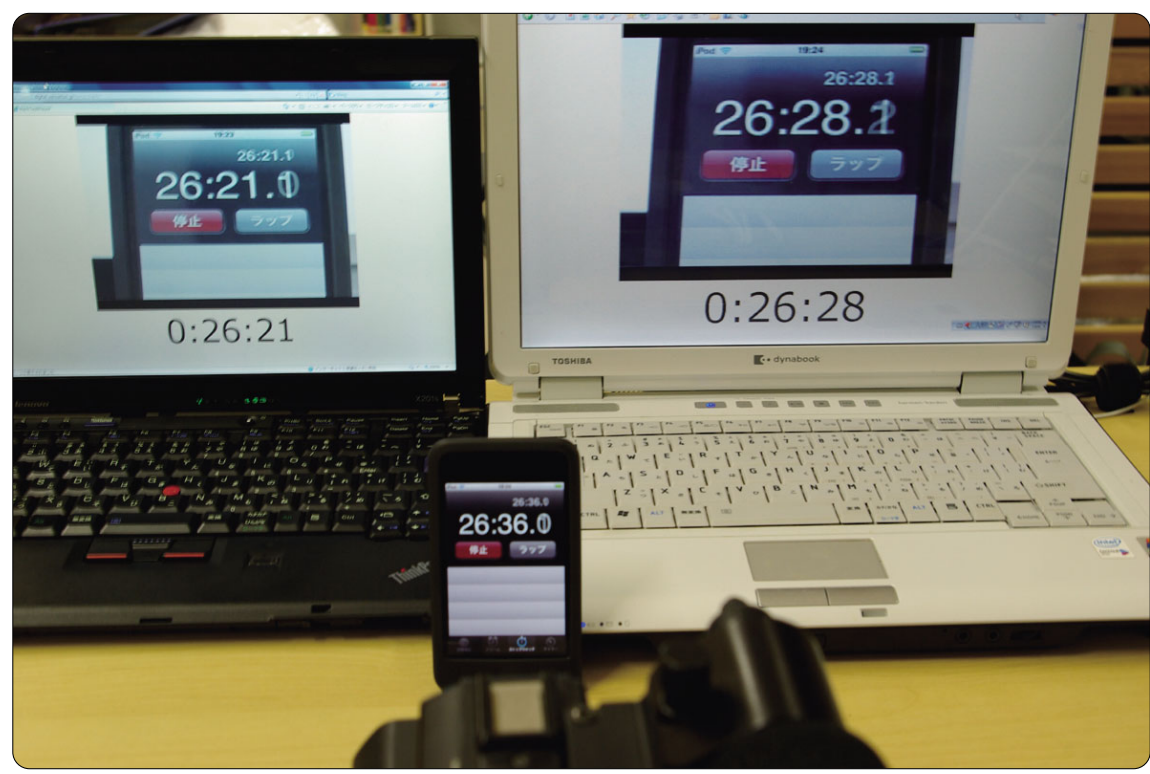

図7 ライブ配信サービスにおける「時刻のずれ」

だゴールしていないネットユーザが多 数存在するからです.

図7は, 中央の時計を手前のカメラ で撮影し配信している映像を, 左右2 台のPCで視聴しているものです．配 信は, Windows Mediaサービスで行 っています。現場時刻と映像内時刻が ずれていること，映像内時刻同士もず れていることが確認できるでしょう.

さらに，ビデオ画面内の時刻とビデ オ画面直下のブラウザで表示している 時刻が一致していることも確認できる と思います．これによりライブ内容と 同期させたCM提示など，インターネ ットならではの表現が可能になります。

\section{5. むす び}

当社は，静岡大学情報学部から生ま れました．よく誤解されるのですが,
一ネットの映像メディアが持つ「重さ」 と，それ故の「説得力」を実感していま す，当社は技術力で，映像メディアの 軽快な利用スタイルを提案・実現し, 教育やビジネス現場を大きく発展させ るサービスを本気で狙っていきます。

(2010年9月10日受付)

\section{〔文 献〕}

1）デジタルセンセーション, http://www digital -sensation.jp/

2）竹林洋一：“人間支援のためのバウンダリ ーレスなAI研究に向けて”, 人工知能学会誌, 16, 4, pp.550-559 (2001)

3) 竹林洋一：“ヒューマンインタフェースの 観点から見た気の利いた情報システム”, 信 学誌, 82, 4, pp.310-318 (1999)

4) メディアイメージ, http://www.mi-j.com/

5）日本ディジタル・プロセシング・システム ズ, http://www.dpsj.co.jp/

6) M. ミンスキー (竹林洋一訳) ：“ミンスキ 一博士の脳の探求 - 常識 · 感情 - 自己と は一”, 共立出版 (2009) 必要なツールを開発するのは基礎で す.この基礎力を高いしベルで保持し ながら,コンピュータという箱から目 を離して視野を広げ，人の活動を含め た環境全体を情報化 (情報の集合とし てデザイン)します。そうすると，環 境全体をコンピュータの処理対象にで き, 分析や検索, シミュレーションな よ゙，多様な技術を現場に応用できます． システム開発には芸術的な設計の感覚 (才能)が必要なのです6).

インターネットの映像メディアは, ようやく技術的に「使える」ところまで は来ました，次のステップは，ビジネ スを意識したサービスデザインとサー ビス化技術の実現です。

私たちは, 数多くの実践からインタ

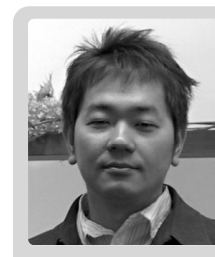

2000年, 大阪大学大学院修 了. 静岡大学情報学部助手 を経て，2004年より，デジ タルセンセーション (株) 代 表取締役社長を兼務. 2009 年に, 静岡大学を退職し, 社長専任. 父親の影響で3歳

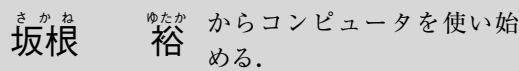

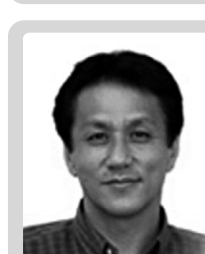

1980年，東北大学博士課程 修了後, (株) 東芝入社. 以 来, 音声対話, ヒューマン インタフェース, 人工知能 システムの研究実用化に従 事. MITメディア研究所客 員研究員, (株) 東芝研究開 竹ばが洋いち発センター技監などを経て， 丁林 現在, 静岡大学創造科学技 術大学院教授. 2004年より, デジタルセンセー ション (株) 代表取締役会長兼務. 正会員. 